Zagazig J. Agric. Res., Vol. 43 No. (1) 2016

http:/www.journals.zu.edu.eg/journalDisplay.aspx? Journalld=1\&queryType=Master

\title{
RESPONSE OF SOME WHEAT CULTIVARS TO VARYING SOWING DATES AND NITROGEN FERTILIZER LEVELS UNDER SANDY SOIL CONDITIONS
}

\author{
AbdAllah A.H. Fadle ${ }^{1 *}$, A.Y.A. El-Bana ${ }^{2}$, A.E.A. Omar ${ }^{2}$ and M.E.I. Abdul Hamid ${ }^{2}$ \\ 1. Agent. Agric., Manag., Fakous, Sharkia, Egypt \\ 2. Agron. Dept., Fac. Agric., Zagazig Univ., Egypt
}

\begin{abstract}
Two field experiments were conducted at Abazah Village, Faqous District, Sharkia Governorate, Egypt during 2013/2014 and 2014/2015 growing seasons, to study the effect of three sowing dates (November $10^{\text {th }}$, November $30^{\text {th }}$ and December $20^{\text {th }}$ ), three nitrogen fertilizer levels (60, 90 and $120 \mathrm{~kg}$ N/fad.) and four wheat cultivars (Gemmizea 11, Sids 12, Giza 164 and Misr 1) on yield and yield attributes of wheat under sandy soil conditions. Each experiment included 36 treatments, which were the combinations of three sowing dates, three nitrogen fertilizer levels and four wheat cultivars. A split-split plot design with three replicates was used where; the main plots were devoted to sowing dates while the sub plots were occupied by nitrogen fertilizer levels whereas wheat cultivars were allotted in the sub-sub plots. The obtained results revealed that plant height, number of spikes $/ \mathrm{m}^{2}$, spike length, number of spikelets/spike, number of grains/spike, 1000-grain weight as well as grain, straw and biological yields/fad., were significantly higher on November, $30^{\text {th }}$ sowing as compared to other sowing dates. Nitrogen fertilizer level affected significantly all studied traits. Since, increasing nitrogen fertilizer level up to $120 \mathrm{~kg} \mathrm{~N} /$ fad., significantly increased plant height, spike length, number of spikelets/spike, number of grains/ spike as well as grain, straw and biological yields/fad., while 1000 -grain weight significantly decreased. On the other side, number of spikes $/ \mathrm{m}^{2}$ was responded only to nitrogen up to $90 \mathrm{~kg} \mathrm{~N} / \mathrm{fad}$. (Combined data). Misr $1 \mathrm{cv}$. recorded the maximum plant height, number of spikes $/ \mathrm{m}^{2}$ as well as grain, straw and biological yields/fad., but without significant differences than Gemmizea 11 in grain and biological yields. Otherwise Sids 12 surpassed other cultivars in spike length, number of spikelets/spike, number of grains/spike and 1000-grain weight.
\end{abstract}

Key words: Wheat cultivars, sowing dates, nitrogen levels, sandy soil, yield and its attributes.

\section{INTRODUCTION}

Wheat (Triticum aestivum, L.) is one of the most important cereal crops in the world and it has the widest distribution among cereal crops. The crop is primarily grown for its grain, which is consumed as human food. Wheat also is the most important cereal crop in Egypt and accounts for about $40.2 \%$ of the total cereal production with acreage of 3.024 million faddans, produced an average of 8.371 million tons of grain in 2011 (Ministry of Agriculture and Land Reclamation, 2012).
The high and rising consumption of subsidized wheat is a central problem. At 172 kilos per capita a year, Egypt's wheat consumption is among the highest in the world. Another problem is the cultivation of Egyption clover (berseem) for animal feed, in a larger acerage than any other winter crop in the country. Therefore, raising wheat in newly cultivated area has become a cornerstone for sustaining its national production.

Improving the productivity of this crop is a main task due to its short supply which mandated importing about $50 \%$ of the needed

\footnotetext{
* Corresponding author. Tel.: + 01224604990

E-mail address: adel_elbna@yahoo.com
} 
wheat. Therefore, many efforts were done to increase wheat cultivated area in sandy soils in Egypt.

Increasing wheat production could be possible via two ways: horizontal expansion through increasing the wheat cultivated area and vertical expansion through the development of new cultivars having the high potentiality and subsequently implementing the proper cultural practices (Ragab, 2011).

Sowing date is one of the most important agronomic factors involved in proceeding high yielding of small grain cereal crops, which affects timing and duration of the vegetative and reproductive stages. Optimum sowing date of different wheat cultivars, varies with regions depending on growing conditions of a specific tract that could be assessed by planting them at different times. On the other hand, late sowing of wheat might expose the crop plants to higher temperature during and after heading, resulting in reduced number of spikes per square meter and number of grains/spike (Randhawa et al., 1977). Late sowing mostly accompanied with late seedling emergence due to low day and night temperatures. Aftab et al. (2004), in Pakistan reported that, biomass accumulation, grain yield, number of spikes/ $\mathrm{m}^{2}$ and thousand grain weight of wheat were increased with early sowing (early November) over late sowing (December). Many workers reported that early sowing of wheat, significantly increased yield and its attributes compared with late sowing (Shafiq, 2004; Akhtar et al., 2006; Hardan, 2008 ; Swelam et al., 2010). El-Gizawy (2009), in Egypt showed that the highest values of number of tillers and spikes $/ \mathrm{m}^{2}, 1000$-grain weight and grain yield per unit area were obtained when wheat was sown on mid of November but early or delayed planting caused a significant decrease in forenamed traits. Amin (2010), found that early sowing $\left(15^{\text {th }}\right.$ of November) increased grain weight/spike, grain yield/ fad., but late sowing ( $30^{\text {th }}$ November) gave much spikelets/ spike, spikes $/ \mathrm{m}^{2}$. El-Sarag and Ismaeil (2013), in their study on the effect of the potential impact of three sowing dates; first sowing date $\left(16^{\text {th }}\right.$ November), second sowing date $\left(1^{\text {st }}\right.$ December) and third sowing date $\left(16^{\text {th }}\right.$ December) on two wheat cultivars (Giza 168 and Sakha 93) showed that the second sowing date caused superiority in wheat grain yield and most of its components. Fayed et al. (2015), in Egypt and under Saini conditions, found that the highest values of spike length and thousand grain weight were recorded by Gemmeiza-9 cultivar under early sowing date (October, 15). However, the highest values of spike weight, grain yield and dry biological yield were obtained when the same cultivar was cultivated under mediate sowing date (mid-November).

Nitrogen is the most important fertilizer element to be added under sandy soil conditions. It plays an important role in plant growth and it is considered the most important fertilizer needed for maximizing yield in most of field crops as well as wheat. The response of wheat to nitrogen levels is affecting with many factors such as cultivar, soil, climatic and proceeding crop. In this connection, several research workers got significant response to nitrogen level up to $75 \mathrm{~kg} \mathrm{~N}$ /fad., under old soil (El-Gizawy, 2010 and Swelam et al., 2010). However, Mehasen and Mohamed (2005) showed higher response of wheat grain yield when they added $90 \mathrm{~kg} \mathrm{~N} / \mathrm{fad}$. Moreover, Hassan and Gaballah (2000); Sawires (2000) and Ahmed (2009) found that this response reaching $100 \mathrm{~kg} \mathrm{~N} /$ fad., (sandy soil). Furthermore, Ashmawy and Abo-Warda (2002), Abdul Galil et al. (2003) and Ali et al. (2004) recorded higher responses when they added 120 $\mathrm{kg} \mathrm{N} /$ fad., under sandy soil conditions. Iqbal et al. (2012), in Pakistan investigated five nitrogen levels (i.e. $0,75,100,125$ and $150 \mathrm{~kg} \mathrm{~N} / \mathrm{ha}$ ) on wheat. They reported that plant height, number of tillers $/ \mathrm{m}^{2}$, spike length, number of spikelets/spike, number of grains/spike, 1000grain weight, grain yield, biological yield and harvest index were highest at $125 \mathrm{~kg} \mathrm{~N} /$ ha level and lowest at zero level of nitrogen. Abd ElRazek and El-Sheshtawy (2013) tested four nitrogen levels (45, 90, 135 and $180 \mathrm{~kg} / \mathrm{ha}$ ) on wheat yield. They found that increasing nitrogen fertilizer level up to $180 \mathrm{~kg} \mathrm{~N} /$ ha., significantly increased plant height, yield and its attributes compared with the other nitrogen treatments. The values of grain yield (ton/ha) due to increasing nitrogen fertilizer levels were 9.68 for $180 \mathrm{~kg} / \mathrm{ha}$, followed by 8.82 for $135 \mathrm{~kg} \mathrm{~N}, 7.15$ for $90 \mathrm{~kg} \mathrm{~N}$ and $5.46 \mathrm{ton} /$ ha for $45 \mathrm{~kg} \mathrm{~N}$ in the combined analysis. Noureldin et al. (2013), 
reported that increasing $\mathrm{N}$ up to $180 \mathrm{~kg} / \mathrm{ha}$ increased grain yield and its components (number of spikes/ $\mathrm{m}^{2}$, spike length, number of grains per spike, weight of grains per spike, and 1000 grain weight). Youssef et al. (2013), tried four $\mathrm{N}$ levels (i.e. 0, 96, 192 and $288 \mathrm{~kg} / \mathrm{ha}$.) on wheat. They found that increasing $\mathrm{N}$ levels from 0 to $288 \mathrm{~kg} / \mathrm{ha}$., significantly increased number of tillers/plant, number of grains/spike spike length, 1000 grain weight as well grain yields and harvest index while plant height responded to $96 \mathrm{~kg} / \mathrm{ha}$.

Khalid et al. (2014), in Pakistan, tested five different nitrogen levels (i.e. 0, 50, 100, 150 and $200 \mathrm{~kg} \mathrm{~N} / \mathrm{ha}$ ) on wheat yield and yield attributes. They found that, number of spikelets and grains/ spike, 1000 grain weight as well as grain and biological yields/ha., responded up to $100 \mathrm{~kg} \mathrm{~N} /$ ha., while number of tillers $/ \mathrm{m}^{2}$, plant height and harvest index responded up to 150, 200 and 50 $\mathrm{kgN} / \mathrm{ha}$., respectively.

Several investigators reported that wheat cultivars showed significant differences in yield and yield attributes due to differences in their genetic background (Amin, 2010; Swelam et al., 2010 ; Hafez et al., 2012 ; Abd El-kreem and Ahmed, 2013; El-Sarag and Ismaeil, 2013; Geith et al., 2013; Abd El-Lattief, 2014 and Fayed et al., 2015).

Therefore, the objective of the present investigation was to study the performance of four wheat cultivars on different sowing dates under different levels of nitrogen to determine the proper cultivar in proper sowing date and specific of nitrogen.

\section{MATERIALS AND METHODS}

Two field experiments were conducted at Abazah Village, Faqous District, Sharkia Governorate, Egypt during 2013/2014 and 2014/2015 growing seasons, to study the effect of sowing dates, nitrogen fertilizer levels and wheat cultivars on growth, yield and yield attributes of wheat (Triticum aestivum L.).

Each experiment included 36 treatments, which were the combinations of three sowing dates, three nitrogen fertilizer levels and four wheat cultivars as follows:

\section{Sowing Dates}

The three sowing dates used were:

a- November $10^{\text {th }}$ (early).

b- November $30^{\text {th }}$ (moderate).

c- December $20^{\text {th }}$ (late).

\section{Nitrogen fertilizer level}

The three nitrogen fertilizer levels used were $60 \mathrm{Kg} \mathrm{N} / \mathrm{fad}$., $90 \mathrm{Kg} \mathrm{N} / \mathrm{fad}$. and $120 \mathrm{Kg}$ N/fad. These three nitrogen levels were added in six equal splits at sowing, 15 days after sowing and four spilts at every 10 days interval. Nitrogen was added in the form of urea $(46.5 \% \mathrm{~N})$.

\section{Wheat Cultivars}

The four wheat cultivars used were Gemmaza11, Sids 12, Giza 168 and Misr 1 .

\section{Experimental Design}

A split-split plot design with three replicates was used where, the main plots were devoted to sowing dates while the sub plots were occupied by nitrogen fertilizer levels, whereas wheat cultivars were allotted in the sub-sub plots.

\section{Cultural Practices}

Nitrogen fertilizer in form of urea (46.5\%) was added at six equal splits at sowing, 15 days after sowing and four spilts at every 10 days interval.. The preceding crop was maize in both seasons. The sub - sub plot area was $12 \mathrm{~m}^{2}$ (3m. in width $\mathrm{x} 4 \mathrm{~m}$. in length) which included 20 rows, $15 \mathrm{~cm}$ apart. Calcium super phosphate $\left(15.5 \% \mathrm{P}_{2} \mathrm{O}_{5}\right)$ at level of $200 \mathrm{~kg} / \mathrm{fad}$., and potassium sulphate $\left(50 \% \mathrm{~K}_{2} \mathrm{O}\right)$ at level of 100 kg./fad., were added during seedbed preparation. Irrigation was applied as it was needed by the crop (10 days interval). Cultivars were sown using seed rate of $70 \mathrm{~kg} / \mathrm{fad}$., in the two successive seasons. Weeds were controlled manually (two times). The other culture practices were applied as recommended.

The experimental soil was sandy in texture. Some physical and chemical properties of the experimental field soils in the two seasons are presented in Table 1 . Temperature and relative humidity during wheat growing season are shown in Table 2. 
Table 1. Some physical and chemical properties of the experimental soil in the two seasons $(2013 / 2014-2014 / 2015)$

\begin{tabular}{|c|c|c|c|c|}
\hline \multirow[t]{3}{*}{ Soil characteristics } & \multicolumn{4}{|c|}{ Soil depth } \\
\hline & \multicolumn{2}{|c|}{$0-15 \mathrm{~cm}$} & \multicolumn{2}{|c|}{$15-30 \mathrm{~cm}$} \\
\hline & $2013 / 2014$ & $2014 / 2015$ & $2013 / 2014$ & $2014 / 2015$ \\
\hline \multicolumn{5}{|l|}{ 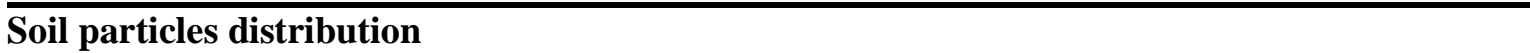 } \\
\hline Sand (\%) & 80.87 & 84.05 & 91.13 & 93.61 \\
\hline Silt (\%) & 12.03 & 10.23 & 7.83 & 4.23 \\
\hline Clay (\%) & 7.10 & 5.72 & 1.04 & 2.16 \\
\hline Textural class & Sandy loam & Sandy loam & Sand & Sand \\
\hline $\mathrm{pH} *$ & 7.98 & 8.11 & 8.32 & 8.49 \\
\hline $\mathrm{EC},(\mathrm{ds} / \mathrm{m})^{*}$ & 0.40 & 0.36 & 0.14 & 0.13 \\
\hline \multicolumn{5}{|c|}{ Soluble cations and anions (mmole/l)* } \\
\hline $\mathrm{Ca}++$ & 1.4 & 1.3 & 0.42 & 0.22 \\
\hline $\mathrm{Mg}++$ & 0.7 & 0.6 & 0.13 & 0.23 \\
\hline $\mathrm{Na}+$ & 1.55 & 1.38 & 0.64 & 0.55 \\
\hline $\mathrm{K}+$ & 0.35 & 0.32 & 0.21 & 0.30 \\
\hline $\mathrm{CO}^{=}$ & - & - & - & - \\
\hline $\mathrm{HCO}^{-}$ & 1.32 & 1.19 & 0.56 & 0.37 \\
\hline $\mathrm{Cl}^{-}$ & 1.29 & 1.16 & 0.43 & 0.51 \\
\hline $\mathrm{SO}^{=}$ & 1.34 & 1.25 & 0.41 & 0.37 \\
\hline Available N,(mg/ Kg soil) & 40.33 & 53.91 & 36.72 & 31.49 \\
\hline Available P,(mg/ Kg soil) & 7.26 & 6.24 & 5.11 & 3.95 \\
\hline Available K,(mg/ Kg soil) & 60.40 & 58.09 & 53.95 & 49.81 \\
\hline
\end{tabular}

*Soil-water suspension 1:2.5

Table 2. Average monthly temperature and relative humidity during growing seasons of wheat

\begin{tabular}{|c|c|c|c|c|c|c|c|}
\hline \multirow[t]{2}{*}{ Month } & \multicolumn{3}{|c|}{${\text { Temperature } \mathrm{C}^{0}}^{0}$} & \multicolumn{3}{|c|}{ Relative humidity (\% ) } & \multirow{2}{*}{$\begin{array}{c}\text { Rainfall } \\
\text { Mean } \\
(\mathrm{mm})\end{array}$} \\
\hline & Max & Min & Mean & Max & Min & Mean & \\
\hline \multicolumn{8}{|c|}{$2013 / 2014$ season } \\
\hline November & 29.4 & 14.7 & 22.1 & 63.0 & 36.0 & 49.5 & 0.140 \\
\hline December & 19.4 & 14.0 & 16.7 & 76.3 & 43.8 & 60.1 & 0.150 \\
\hline January & 17.8 & 14.5 & 16.2 & 80.5 & 46.5 & 63.5 & 0.185 \\
\hline February & 22.1 & 13.9 & 18.0 & 77.8 & 51.1 & 64.5 & 0.530 \\
\hline March & 23.6 & 13.7 & 18.7 & 75.6 & 45.1 & 60.4 & 0.210 \\
\hline April & 29.0 & 15.5 & 22.3 & 68.6 & 41.1 & 54.8 & - \\
\hline \multicolumn{8}{|c|}{ 2014/2015 season } \\
\hline November & 30.2 & 16.0 & 23.1 & 64.0 & 43.0 & 53.5 & - \\
\hline December & 20.9 & 14.6 & 17.8 & 79.4 & 44.2 & 61.8 & 0.560 \\
\hline January & 18.6 & 15.1 & 16.9 & 80.1 & 54.5 & 67.3 & 0.255 \\
\hline February & 23.7 & 16.2 & 20.0 & 82.5 & 55.6 & 69.1 & 0.190 \\
\hline March & 25.5 & 14.7 & 20.1 & 80.0 & 51.3 & 65.7 & 0.225 \\
\hline April & 30.1 & 17.0 & 23.6 & 73.4 & 49.5 & 61.5 & - \\
\hline
\end{tabular}




\section{Recorded Data}

\section{Yield and yield attributes}

At harvest, yield and yield attributes were determine as follows:

\section{Plant height (cm)}

Twenty tillers were taken at random from each plot at 3 places, their long heights were measured in $\mathrm{cm}$ and means were determined.

\section{Number of spikes/ $\mathbf{m}^{2}$}

An area of $0.5 \mathrm{~m}^{2}$ was selected at random in each plot to count total number of spikes/spike.

1- Spike length (cm).

2- Number of spikelets/spike.

3- Number of grains/spike.

Ten spikes were randomly taken from each unit area in each plot. Each spike was threshed separately and grains of each spike were counted and averaged.

\section{4- Thousand grain weight (g).}

Thousand grains were counted at random from each plot and their weights were taken with a spring balance.

The final straw yield ton/fad., grain yield ardab/ fad., and biological yield ton/fad., were determined from a central area of $0.75 \mathrm{~m}^{2}$ (5 rows by long of one meter) in both seasons

\section{Statistical Analysis}

The data obtained from each trial was subjected to the analysis of variance of split split plot design using computer program MSTAT-C as described by Snedecor and Cochran (1981). Then, a combined analysis was made for the data of the two seasons after test the homogeneity of error by Bartellet test (Steel et al., 1997). The differences among treatments were compared using Duncan's multiple range test (Duncan, 1955), where means had the different letters were statistically significant, while those means followed by the same letters were statistically insignificant. In the interaction tables, capital and small letters were used to compare between means in rows and columns, respectively.

\section{RESULTS AND DISCUSSION}

\section{Plant Height, Number of Spikes $/ \mathrm{m}^{2}$ and Spike Length}

Data presented in Table 3 show the influence of sowing dates, nitrogen fertilizer levels and cultivars on plant height, number of spikes $/ \mathrm{m}^{2}$ and spike length of wheat during both growing seasons and their combined.

Regarding the effect of sowing dates, it was quite evident that delaying sowing to December $20^{\text {th }}$ was followed by a significant decrease in each of plant height and number of spikes $/ \mathrm{m}^{2}$ compared with early or moderate sowing on November $10^{\text {th }}$ and November $30^{\text {th }}$, respectively. Results of the combined indicated that the tallest plants $(122.17 \mathrm{~cm})$ was observed at moderate sowing (November, $30^{\text {th }}$ ), while the shortest plants $(114.31 \mathrm{~cm})$ was recorded by later sowing (December, $20^{\text {th }}$ ). This finding might be attributed to other optimum environmental factors that encouraged growth and early development of plant sown on November $30^{\text {th }}$ rather than those sown on November, $10^{\text {th }}$ or December, $20^{\text {th }}$. Maximum number of spikes $/ \mathrm{m}^{2}$ was recorded by sowing wheat plants on November $30^{\text {th }}$ (424.8) while, minimum number of spikes $/ \mathrm{m}^{2}$ was recorded by late sowing on December $20^{\text {th }}$ (359.2). This might be due to the high efficiency of plants to convert solar energy to chemical energy which increased number of spikes $/ \mathrm{m}^{2}$ with sowing on $30^{\text {th }}$ Nov. than the other tested sowing dates. Also, the longest spike $(12.19 \mathrm{~cm})$ was recorded due to sowing on November, $30^{\text {th }}$ while the shortest one was recorded with sown on December, $20^{\text {th }}$ (11.635 $\mathrm{cm})$ and on November, $10^{\text {th }}(11.564 \mathrm{~cm})$. These results are in accordance with those reported by. El-Gizawy (2009), Amin (2010), Swelam et al. (2010) and El-Sarag and Ismaeil (2013).

Concerning the effect of nitrogen fertilizer levels, results presented in Table 3 show that $\mathrm{N}$ fertilizer levels had a significant effect on plant height, number of spikes $/ \mathrm{m}^{2}$ and spike length. Increasing $\mathrm{N}$ fertilizer level from 60 to $120 \mathrm{~kg}$ $\mathrm{N} /$ fad., was associated with significant increase in formentioned traits in both growing seasons and their combined analysis, while number of spikes $/ \mathrm{m}^{2}$ responded up to application of $120 \mathrm{~kg}$ $\mathrm{N} / \mathrm{fad}$., in both seasons and thier combined analysis. 
Table 3. Plant height, No. of spikes $/ \mathrm{m}^{2}$ and spike length of wheat as affected by sowing dates, nitrogen fertilizer levels, cultivars and their interactions during two successive winter seasons (2013/2014 and 2014/2015) as well as their combined.

\begin{tabular}{|c|c|c|c|c|c|c|c|c|c|}
\hline \multirow{2}{*}{$\begin{array}{l}\text { Main effects and } \\
\text { interactions }\end{array}$} & \multicolumn{3}{|c|}{ Plant height $(\mathrm{cm})$} & \multicolumn{3}{|c|}{ Number of spikes $/ \mathrm{m}^{2}$} & \multicolumn{3}{|c|}{ Spike length (cm) } \\
\hline & $\begin{array}{c}1^{\text {st }} \\
\text { season }\end{array}$ & $\begin{array}{c}2^{\text {nd }} \\
\text { season }\end{array}$ & Com. & $\begin{array}{c}1^{\text {st }} \\
\text { season }\end{array}$ & $\begin{array}{c}2^{\text {nd }} \\
\text { season }\end{array}$ & Com. & $\begin{array}{c}1^{\text {st }} \\
\text { season }\end{array}$ & $\begin{array}{c}2^{\text {nd }} \\
\text { season }\end{array}$ & Com. \\
\hline \multicolumn{10}{|l|}{ Sowing date (S) } \\
\hline November $10^{\text {th }}$ & $121.06 \mathrm{~b}$ & $112.47 \mathrm{~b}$ & 116.76b & 382.7b & $371.6 b$ & $377.2 b$ & $12.31 b$ & $10.81 b$ & $11.56 b$ \\
\hline November $30^{\text {th }}$ & $127.22 \mathrm{a}$ & 117.11a & $122.17 \mathrm{a}$ & 443.3a & $406.2 \mathrm{a}$ & $424.8 \mathrm{a}$ & 13.13a & $11.25 \mathrm{a}$ & 12.19a \\
\hline December $20^{\text {th }}$ & $117.72 b$ & $110.89 b$ & 114.31c & 361.6b & $356.8 c$ & $359.2 c$ & $12.40 \mathrm{~b}$ & $10.86 b$ & 11.63b \\
\hline F. test & $* *$ & $* *$ & $* *$ & $* *$ & $* *$ & $* *$ & $* *$ & $*$ & $* *$ \\
\hline \multicolumn{10}{|c|}{ Nitrogen fertilizer level (N) } \\
\hline $60 \mathrm{~kg} / \mathrm{fad}$. & $117.67 \mathrm{c}$ & 111.22c & $114.44 \mathrm{c}$ & $346.6 c$ & $382.9 \mathrm{~b}$ & $347.3 c$ & $12.29 \mathrm{~b}$ & $10.51 b$ & $11.40 \mathrm{~b}$ \\
\hline 90 kg/fad. & $121.72 b$ & 113.61b & 117.67b & 407.1b & 348.1c & 377..6b & $12.43 \mathrm{~b}$ & $10.75 b$ & 11.59b \\
\hline 120 kg/fad. & 126.61a & $115.64 a$ & $121.12 \mathrm{a}$ & 433.9a & 403.8a & 418.8a & 13.11a & 11.65a & 12.38a \\
\hline F. test & $* *$ & $* *$ & $* *$ & $* *$ & $*$ & $* *$ & $* *$ & $* *$ & $* *$ \\
\hline \multicolumn{10}{|l|}{ Cultivar (C) } \\
\hline Gemmeiza 11 & 122.59ab & $114.41 a$ & 118.50a & 405.7ab & 378.3a & $392.0 \mathrm{~b}$ & $12.79 b$ & 11.32b & $12.05 b$ \\
\hline Sids 12 & 121.22ab & $114.52 a$ & 117.87a & 355.7c & 339.0b & $347.4 \mathrm{c}$ & 13.66a & 11.61a & $12.64 a$ \\
\hline Giza 168 & $120.74 b$ & $111.41 b$ & 116.07b & 392.7b & 389.1a & 390.9b & $12.29 b$ & $10.73 \mathrm{c}$ & 11.51c \\
\hline Misr 1 & $123.44 a$ & 113.63a & $118.54 a$ & $429.2 \mathrm{a}$ & 406.4a & 417.8a & 11.71c & $10.22 \mathrm{c}$ & 10.97d \\
\hline F. test & $* *$ & $* *$ & $* *$ & $* *$ & $* *$ & $* *$ & $* *$ & $* *$ & $* *$ \\
\hline \multicolumn{10}{|l|}{ Interactions } \\
\hline $\mathrm{S} \times \mathrm{N}$ & NS & NS & NS & $*$ & NS & $*$ & $*$ & NS & NS \\
\hline $\mathrm{S} \times \mathrm{C}$ & NS & $* *$ & NS & $* *$ & $*$ & $*$ & NS & $* *$ & $* *$ \\
\hline $\mathrm{N} \times \mathrm{C}$ & $* *$ & $*$ & $* *$ & $*$ & $* *$ & $* *$ & NS & $* *$ & $*$ \\
\hline
\end{tabular}

*, ** and NS. indicate significant at 0.05 and 0.01 levels and insignificant of differences, in respective order.

Table 3-a. Plant height " $\mathrm{cm}$ "as affected by the interaction between nitrogen fertilizer levels and cultivars (combined data)

\begin{tabular}{lccc}
\hline Cultivar & \multicolumn{3}{c}{ Nitrogen fertilizer level } \\
\cline { 2 - 4 } & $\mathbf{6 0} \mathbf{~ k g} / \mathbf{f a d}$ & $\mathbf{9 0} \mathbf{~ k g} / \mathbf{f a d}$. & $\mathbf{1 2 0} \mathbf{~ k g} / \mathbf{f a d}$. \\
\hline \multirow{2}{*}{ Gemmieza 11 } & $\mathrm{C}$ & $\mathrm{B}$ & $\mathrm{A}$ \\
& $113.39 \mathrm{a}$ & $119.17 \mathrm{a}$ & $122.94 \mathrm{a}$ \\
Sids 12 & $\mathrm{B}$ & $\mathrm{B}$ & $\mathrm{A}$ \\
& $115.17 \mathrm{a}$ & $115.83 \mathrm{~b}$ & $122.61 \mathrm{a}$ \\
Giza 168 & $\mathrm{B}$ & $\mathrm{A}$ & $\mathrm{A}$ \\
& $113.94 \mathrm{a}$ & $117.33 \mathrm{ab}$ & $116.94 \mathrm{~b}$ \\
Misr 1 & $\mathrm{C}$ & $\mathrm{B}$ & $\mathrm{A}$ \\
\hline
\end{tabular}


Table 3-b. Number of spikes $/ \mathrm{m}^{2}$ as affected by the interaction between sowing dates and nitrogen fertilizer levels (combined data)

\begin{tabular}{lccc}
\hline Nitrogen fertilizer & \multicolumn{3}{c}{ Sowing date } \\
\cline { 2 - 4 } level & ${\text { November } \mathbf{1 0}^{\text {th }}}$ & ${\text { November } \mathbf{3 0}^{\text {th }}}$ & December 20 $^{\text {th }}$ \\
\hline & $\mathrm{B}$ & $\mathrm{A}$ & $\mathrm{B}$ \\
$\mathbf{6 0} \mathbf{~ k g / f a d . ~}$ & $331.58 \mathrm{~b}$ & $372.45 \mathrm{~b}$ & $337.87 \mathrm{~b}$ \\
& $\mathrm{~B}$ & $\mathrm{~A}$ & $\mathrm{C}$ \\
$\mathbf{9 0} \mathbf{~ k g / f a d . ~}$ & $390.45 \mathrm{a}$ & $436.45 \mathrm{a}$ & $357.95 \mathrm{ab}$ \\
& $\mathrm{C}$ & $\mathrm{A}$ & $\mathrm{B}$ \\
$\mathbf{1 2 0} \mathbf{~ k g / f a d . ~}$ & $409.50 \mathrm{a}$ & $465.33 \mathrm{a}$ & $381.75 \mathrm{a}$ \\
\hline
\end{tabular}

Table 3-c. Number of spikes $/ \mathrm{m}^{2}$ as affected by the interaction between sowing dates and cultivars (combined data)

\begin{tabular}{lccc}
\hline Cultivar & \multicolumn{3}{c}{ Sowing date } \\
\cline { 2 - 4 } & November 10 $^{\text {th }}$ & November30 $^{\text {th }}$ & December 20 $^{\text {th }}$ \\
\hline \multirow{2}{*}{ Gemmieza 11 } & B & A & B \\
& $376.72 ~ b$ & $435.16 \mathrm{ab}$ & $364.11 \mathrm{~b}$ \\
Sids 12 & B & A & B \\
& $337.56 \mathrm{c}$ & $377.83 \mathrm{~b}$ & $326.78 \mathrm{c}$ \\
Giza 168 & $\mathrm{B}$ & $\mathrm{A}$ & $\mathrm{C}$ \\
& $383.11 \mathrm{~b}$ & $432.72 \mathrm{ab}$ & $357.00 \mathrm{~b}$ \\
Misr 1 & $\mathrm{B}$ & $\mathrm{A}$ & $\mathrm{C}$ \\
\hline
\end{tabular}

Table 3-d. Number of spikes $/ \mathrm{m}^{2}$ as affected by the interaction between nitrogen fertilizer levels and cultivars (combined data).

\begin{tabular}{|c|c|c|c|}
\hline \multirow[t]{2}{*}{ Cultivar } & \multicolumn{3}{|c|}{ Nitrogen fertilizer level } \\
\hline & 60 kg/fad. & $90 \mathrm{~kg} / \mathrm{fad}$. & $120 \mathrm{~kg} / \mathrm{fad}$. \\
\hline & $\mathrm{C}$ & $\mathrm{B}$ & $A$ \\
\hline \multirow[t]{2}{*}{ Gemmieza 11} & $355.05 \mathrm{~b}$ & $398.16 \mathrm{~b}$ & $422.77 \mathrm{~b}$ \\
\hline & $\mathrm{C}$ & B & A \\
\hline \multirow[t]{2}{*}{ Sids 12} & 298.39 c & 358.83 c & 384.94 c \\
\hline & $\mathrm{C}$ & B & A \\
\hline \multirow[t]{2}{*}{ Giza 168} & $355.89 \mathrm{~b}$ & $396.72 \mathrm{~b}$ & $420.22 \mathrm{~b}$ \\
\hline & $\mathrm{C}$ & $\mathrm{B}$ & A \\
\hline Misr 1 & 379.89 a & $426.11 \mathrm{a}$ & $447.50 \mathrm{a}$ \\
\hline
\end{tabular}


Table 3-e. Spike length "cm" as affected by the interaction between sowing dates and cultivars (combined data)

\begin{tabular}{lccc}
\hline Cultivar & \multicolumn{3}{c}{ Sowing date } \\
\cline { 2 - 4 } & November 10 $^{\text {th }}$ & ${\text { November } \mathbf{3 0}^{\text {th }}}$ & December 20 $^{\text {th }}$ \\
\hline Gemmieza 11 & $\mathrm{B}$ & $\mathrm{A}$ & $\mathrm{AB}$ \\
& $11.650 \mathrm{~b}$ & $12.439 \mathrm{~b}$ & $12.089 \mathrm{a}$ \\
Sids 12 & $\mathrm{B}$ & $\mathrm{A}$ & $\mathrm{B}$ \\
& $12.139 \mathrm{a}$ & $13.661 \mathrm{a}$ & $12.122 \mathrm{a}$ \\
Giza 168 & $\mathrm{A}$ & $\mathrm{A}$ & $\mathrm{A}$ \\
& $11.483 \mathrm{bc}$ & $11.472 \mathrm{c}$ & $11.589 \mathrm{a}$ \\
Misr 1 & $\mathrm{A}$ & $\mathrm{A}$ & $\mathrm{A}$ \\
\hline
\end{tabular}

Table 3-f. Spike length as affected by the interaction between nitrogen fertilizer levels and cultivars (combined data)

\begin{tabular}{lccc}
\hline Cultivar & \multicolumn{3}{c}{ Nitrogen fertilizer level } \\
\cline { 2 - 4 } & $\mathbf{6 0} \mathbf{~ k g / f a d}$ & $\mathbf{9 0} \mathbf{~ k g} / \mathbf{f a d}$ & $\mathbf{1 2 0} \mathbf{~ k g / f a d}$. \\
\hline Gemmieza 11 & $\mathrm{B}$ & $\mathrm{A}$ & $\mathrm{A}$ \\
& $11.578 \mathrm{~b}$ & $12.189 \mathrm{a}$ & $12.411 \mathrm{~b}$ \\
Sids 12 & $\mathrm{B}$ & $\mathrm{B}$ & $\mathrm{A}$ \\
& $12.183 \mathrm{a}$ & $12.117 \mathrm{a}$ & $13.622 \mathrm{a}$ \\
Giza 168 & $\mathrm{B}$ & $\mathrm{B}$ & $\mathrm{A}$ \\
& $11.261 \mathrm{~b}$ & $11.128 \mathrm{~b}$ & $12.156 \mathrm{~b}$ \\
Misr 1 & $\mathrm{B}$ & $\mathrm{A}$ & $\mathrm{A}$ \\
\hline
\end{tabular}

These results confirm the vital role of nitrogen in cell division as well as building organic metabolites. These results are in agreement with those obtained by Ashmawy and Abo-Warda (2002), Abdul Galil et al. (2003) and Ali et al. (2004) and Iqbal et al. (2012).

Respecting varietal differences, it is clear that Misr 1cv, Gemmieza $11 \mathrm{cv}$ and Sids $12 \mathrm{cv}$ gave taller plants without significant differences (Table 3), while the shortest plants were recorded by Giza $168 \mathrm{cv}$ in both seasons and combined. Misr $1 \mathrm{cv}$ gave the highest number of spikes $/ \mathrm{m}^{2}$ followed by Gemmizea 11 then Giza $168 \mathrm{cv}$ (combined analysis) while, Sids 12cv recorded the lowest ones in both growing seasons and their combined. Sids $12 \mathrm{cv}$ had longest spike followed by Gemmizea $11 \mathrm{cv}$ then Giza 168cv (combined analysis), while the shortest spike length was recorded by Misr 1 in both growing seasons and their combined analysis. It could be concluded that varietal differences among wheat cultivars may be due to geneticall make up. These results are in a good line with those obtained by (Amin, 2010; 
Hafez et al., 2012; El-Sarag and Ismaeil, 2013; Abd E l-Lattief, 2014 and Fayed et al., 2015.

Furthermore, the significant interaction between $\mathrm{N}$-fertilizer levels and wheat cultivars in the combined analysis (Table 3-a), revealed that the tallest plant $(122.94 \mathrm{~cm})$ was recorded by Gemmeiza 11 , Sids 12 and Misr $1 \mathrm{cv}$ when high N-level of $120 \mathrm{kgN} / \mathrm{fad}$., was applied. Otherwise, the shorter plant was recorded for all cultivars when low nitrogen fertilizer level of 60 kg N/fad., was applied.

Regarding the significant interaction between sowing dates and nitrogen fertilizer levels on number of spikes $/ \mathrm{m}^{2}$ (Table 3-b), the results indicated that the highest number of spikes $/ \mathrm{m}^{2}$ were obtained with wheat sown on November, $30^{\text {th }}$ and fertilized with 90 or $120 \mathrm{~kg} \mathrm{~N} / \mathrm{fad}$., without significant differences between both levels of 90 and $120 \mathrm{kgN} / \mathrm{fad}$. These results are in accordance with those reported by Amin (2010). With respect to the significant interaction between sowing dates and wheat cultivars in the combined analysis (Table 3c), the obtained results showed that maximum number of spikes/ $\mathrm{m}^{2}$ (453.28) was achieved by Misr $1 \mathrm{cv}$ when sowing took place on November, $30^{\text {th }}$, while the lowest number of spikes $/ \mathrm{m}^{2}$ (326.78) was obtained by Sids $12 \mathrm{cv}$. when was sown on November, $10^{\text {th }}$. The significant interaction between sowing dates and cultivars shows the sensitivity of different cultivars to photoperiod and temperature differently for plant height. Likely, the significant interaction between nitrogen fertilizer levels and cultivars (Table 3d) indicated that, the highest number of spikes $/ \mathrm{m}^{2}$ (447.50) was obtained by Misr $1 \mathrm{cv}$. when $120 \mathrm{~kg} \mathrm{~N} / \mathrm{fad}$., was added On the other hand the lowest one (298.39) was obtained by Sids $12 \mathrm{cv}$. when fertilized with $60 \mathrm{~kg} \mathrm{~N} / \mathrm{fad}$. Spike length $(\mathrm{cm})$ was significantly affected by the interaction between sowing dates and cultivars in the combined analysis (Table 3-e). Sowing Sids $12 \mathrm{cv}$ on November, $30^{\text {th }}$ produced the longest spike $(13.661 \mathrm{~cm})$, while shortest spike $(10.739 \mathrm{~cm})$ was obtained when Misr 1 cv., was sown on December, $20^{\text {th }}$. The significant interaction between cultivars and sowing dates shows the sensitivity of different cultivars to photoperiod and temperature differently for spike length of wheat. Regarding the significant interaction effects between nitrogen fertilizer levels and wheat cultivars in the combined (Table 3-f) the results indicate that the longest spikes $(13.622 \mathrm{~cm})$ was achieved by Sids 12 cv., when $120 \mathrm{kgN} / \mathrm{fad}$., was applied. However, the shortest spike $(10.611 \mathrm{~cm})$ was recorded by Misr 1 cv., when low nitrogen fertilizer level was applied.

\section{Number of Spikelets/Spike, Number of Grains/ Spike and 1000-Grain Weight}

Data presented in Table 4 show the influence of sowing date, nitrogen fertilizer levels and cultivars on number of spikelets/spike, number of grains/spike and 1000-grain weight of wheat during both growing seasons and their combined.

Regarding the effect of sowing date, the obtained results clearly indicated that sowing dates had highly significant effect on number of spikelets/spike in the $1^{\text {st }}$ season and significant in the $2^{\text {nd }}$ season as well as those of the combined of both seasons. Results of the combined indicated that wheat sown on November, $30^{\text {th }}$ recorded highest number of spikelets/spike which was 20.406 compared with 18.944 and 18.672 for wheat sown early (November, $10^{\text {th }}$ ) or late (December, 20 $0^{\text {th }}$ ), respectively. The obtained results clearly indicated that sowing dates had a significant effect on number of grains/spike in the $2 \mathrm{nd}^{\text {th }}$ season and highly significant in the combined of both seasons (Table 4). The highest number of grains /spike (58.28 and 59.06) was recorded on November, $30^{\text {th }}$ sowing date compared to December, $20^{\text {th }}$ sowing which showed lower number of grains/ spike (50.22 and 50.35) in the $2^{\text {nd }}$ season and the combined, respectively. On the other side, the differences did not reach the level of significant in the $1^{\text {st }}$ season. The results indicated significant differences among sowing dates on thousand grain weight $(\mathrm{g})$ in the $1^{\text {st }}$ season and the combined data and highly significant in the $2^{\text {nd }}$ season, where thousand grain weight (g) was significantly decreased due to early (November, $10^{\text {th }}$ ) or late (December, $20^{\text {th }}$ ) sowing without significant difference in the $1^{\text {st }}$ season and the combined data. According to the combined analysis, the heaviest grain weight (44.76 g) was achieved when wheat was sown on November $30^{\text {th }}$, On the other hand, the lighter 1000-grain weight was obtained when wheat was sown early (November, $10^{\text {th }}$ ) or late (December, $20^{\text {th }}$ ). 
Table 4. Number of spikelets/spike, number of grains/spike and 1000-grain weight (g) of wheat as affected by sowing dates, nitrogen fertilizer levels, cultivars and their interactions during two successive winter seasons (2013/2014 and 2014/2015) as well as their combined.

\begin{tabular}{|c|c|c|c|c|c|c|c|c|c|}
\hline \multirow{2}{*}{$\begin{array}{l}\text { Main effects and } \\
\text { interactions }\end{array}$} & \multicolumn{3}{|c|}{$\begin{array}{c}\text { Number of } \\
\text { spikelets/spike }\end{array}$} & \multicolumn{3}{|c|}{ Number of grains/spike } & \multicolumn{3}{|c|}{ 1000-grain weight (g) } \\
\hline & $\begin{array}{c}1^{\text {st }} \\
\text { season }\end{array}$ & $\begin{array}{c}2^{\text {nd }} \\
\text { season }\end{array}$ & Com. & $\begin{array}{c}1^{\text {st }} \\
\text { season }\end{array}$ & $\begin{array}{c}2^{\text {nd }} \\
\text { season }\end{array}$ & Com. & $\begin{array}{c}1^{\text {st }} \\
\text { season }\end{array}$ & $\begin{array}{c}2^{\text {nd }} \\
\text { season }\end{array}$ & $\overline{\text { Com. }}$ \\
\hline \multicolumn{10}{|l|}{ Sowing dates (S) } \\
\hline November $10^{\text {th }}$ & $19.86 b$ & $18.02 b$ & $18.94 b$ & 54.53 & $53.69 b$ & $54.11 b$ & 43.08ab & $42.56 b$ & $42.82 b$ \\
\hline November $30^{\text {th }}$ & 21.64a & 19.16a & $20.40 \mathrm{a}$ & 59.83 & $58.28 \mathrm{a}$ & $59.06 a$ & 44.03a & $45.50 \mathrm{a}$ & $44.76 a$ \\
\hline December $20^{\text {th }}$ & $19.48 b$ & $17.86 \mathrm{~b}$ & $18.67 \mathrm{~b}$ & 50.47 & $50.22 b$ & $50.35 c$ & $42.61 b$ & $41.17 \mathrm{c}$ & $41.89 \mathrm{~b}$ \\
\hline F. test & $* *$ & * & $*$ & N.S & $*$ & $* *$ & $*$ & $* *$ & $*$ \\
\hline \multicolumn{10}{|c|}{ Nitrogen fertilizer level (N) } \\
\hline 60 kg/fad. & 19.63b & $17.48 \mathrm{~b}$ & $18.56 \mathrm{c}$ & 49.89c & $49.28 \mathrm{c}$ & $49.58 c$ & $44.97 a$ & 43.67 & $44.32 \mathrm{a}$ \\
\hline 90 kg/fad. & $20.10 b$ & $18.54 a$ & $19.32 b$ & $56.25 b$ & $53.89 b$ & $55.07 \mathrm{~b}$ & 43.75ab & 43.47 & 43.61ab \\
\hline 120 kg/fad. & $21.25 \mathrm{a}$ & 19.01a & 20.13a & $58.69 a$ & $59.03 a$ & $58.86 a$ & $41.00 \mathrm{~b}$ & 42.08 & 41.54b \\
\hline F. test & $* *$ & $* *$ & $* *$ & $* *$ & $* *$ & $* *$ & $*$ & N.S & $*$ \\
\hline \multicolumn{10}{|l|}{ Cultivar (C) } \\
\hline Gemmeiza 11 & $19.96 b$ & $18.06 \mathrm{~b}$ & $19.01 b$ & $51.85 \mathrm{~b}$ & $54.19 b$ & $53.02 b$ & 43.89b & $41.56 b$ & $42.72 b$ \\
\hline Sids 12 & $23.22 \mathrm{a}$ & 20.13a & $21.67 a$ & 68.93a & $61.26 a$ & $65.09 a$ & 48.37a & 51.89a & 50.13a \\
\hline Giza 168 & $18.65 d$ & $17.46 \mathrm{c}$ & $18.06 \mathrm{~d}$ & 48.93c & 49.19с & 49.06b & $39.74 c$ & 38.89c & 39.31c \\
\hline Misr 1 & $19.48 c$ & 17.73bc & 18.60c & $50.07 \mathrm{bc}$ & $51.63 \mathrm{bc}$ & $50.85 b$ & $40.96 c$ & 39.96bc & $40.46 c$ \\
\hline F. test & $* *$ & $* *$ & $* *$ & $* *$ & $* *$ & $* *$ & $* *$ & $* *$ & $* *$ \\
\hline \multicolumn{10}{|l|}{ Interactions } \\
\hline $\mathrm{S} \times \mathrm{N}$ & NS & NS & NS & NS & $* *$ & $*$ & NS & NS & NS \\
\hline $\mathrm{S} \times \mathrm{C}$ & $*$ & $*$ & $*$ & $* *$ & $*$ & $* *$ & $* *$ & $* *$ & $* *$ \\
\hline $\mathrm{N} \times \mathrm{C}$ & $*$ & NS & $*$ & $* *$ & NS & NS & $*$ & $* *$ & $* *$ \\
\hline
\end{tabular}

*, ** and NS indicate significant at 0.05 and 0.01 levels and insignificant of differences, in respective order.

This might be due to the high efficiency of plants to convert solar energy to chemical energy which increased grain weight with sowing on November, $30^{\text {th }}$ than the other tested sowing dates. These results are supported by data obtained by El-Gizawy (2009), Amin (2010), Swelam et al. (2010), El-Sarag and Ismaeil (2013) and Fayed et al. (2015).

Concerning the influence of nitrogen fertilizer levels, the data obtained show that nitrogen fertilizer levels had highly significant effect on number of spikelets/spike and number of grains/spike (Table 4). It was clearly eviedent from the data of combined that, the highest number of spikelets/spike (20.136) and grains/ spike (58.86) were obtained by applying $120 \mathrm{~kg}$ $\mathrm{N} /$ fad., while the lowest values were recorded with applying $60 \mathrm{~kg} \mathrm{~N} / \mathrm{fad}$., This might be due to that nitrogen fertilizer significantly affected vegetative and reproductive growth of the plant depending upon the availability of needed nutrition which leads to proportional increases in number of spikelets and grains/ spike. Greater 
partitioning of dry matter to spikes due to nitrogen fertilization causes more grains /spike. Regarding, the influence of $\mathrm{N}$ fertilizer levels on thousand grain weight (g), the data obtained show that nitrogen fertilizer levels had not significant effect on thousand grain weight (g) in the $2^{\text {nd }}$ season and significant in the 1 st season as well as those of the combined of both growing seasons (Table 4). Results of the combined analysis revealed that highest values of thousand grain weight (44.32 g) were noted when $60 \mathrm{~kg} \mathrm{~N} / \mathrm{fad}$., was applied, while the lowest value of thousand grain weight $(41.54 \mathrm{~g})$ was recorded with the high level of $(120 \mathrm{~kg} \mathrm{~N} /$ fad.). These results are also in conformity with those reported by Ashmawy and Abo-Warda (2002), Ali et al. (2004), El-Gizawy (2010), Iqbal et al. (2012), Noureldin et al. (2013) and Khalid et al. (2014).

Respecting varietal differences, it is clear that wheat cultivars were differed significantly in their number of spikelets/spike, number of grains/ spike and 1000-grain weight in both seasons and their combined analysis (Table 4). According to combined analysis Sids $12 \mathrm{cV}$ recorded the highest number of spikelets/ spike (21.678), number of grains/spike (65.09) and 1000-grain weight (50.13). While, the lowest number of spikelets /spike was recorded by Giza 168 cv (18.063). However, Giza 168 cv recorded the light 1000-grain weight with at par average with Misr1 in both seasons and their combined analysis. The reasons for differences in number and weight of grains might be attributed to of genetic structure of the cultivars primarily affected by heredity. These results are in harmony with those obtained by (Swelam et al., 2010 ; Hafez et al., 2012; Abd El-Razek et al., 2013; El-Sarag and Ismaeil, 2013; Abd E lLattief, 2014; Fayed et al., 2015).

Regarding the significant interaction effects between sowing dates and wheat cultivars on number of spikelets/spike. (Table 4-a), the results indicate that the highest number of spikelets/spike (22.722) was obtained by Sids 12 CV., when wheat was sown on November, $30^{\text {th }}$. Otherwise, the lowest number of spikelets/spike (17.078) was obtained by Giza $168 \mathrm{cv}$ when wheat was sown on December, $20^{\text {th }}$. The significant interaction between cultivars and sowing dates shows the sensitivity of different cultivars to photoperiod and temperature differently for number of spikelets / spike of wheat. Moreover, the significant interaction between nitrogen fertilizer levels and cultivars on number of spikelets/ spike are presented in (Table 4-b). These results revealed that the highest number of spikelets/spike (22.722) was obtained by Sids $12 \mathrm{cv}$ when high N-level of 120 $\mathrm{kg}$ N/fad., was applied. Otherwise, the lowest number of spikelets/spike (17.267) was recorded by Giza $168 \mathrm{cv}$., when received $60 \mathrm{~kg} \mathrm{~N} / \mathrm{fad}$. Results of the combined data for both growing seasons, presented in Tale (4-c) show the significant interaction between sowing dates and cultivars on number of grains/spike. These results revealed that the highest number of grains/spike (70.05) was obtained by Sids $12 \mathrm{cv}$ with sowing on November, $30^{\text {th }}$. Otherwise, the lowest number of grains/spike (44.94) was obtained by Giza $168 \mathrm{cv}$ with sowing on December, $20^{\text {th }}$. Data of the combined analysis for both seasons, presented in Table (4-d) show the significant interaction between nitrogen fertilizer levels and cultivars on number of grains/spike. The obtained data revealed that the maximum number of grains/spike (67.94) was achieved by Sids $12 \mathrm{cv}$ when high N-level of $120 \mathrm{~kg} \mathrm{~N} / \mathrm{fad}$., was applied. Otherwise, the minimum number of grains/spike (43.05) was obtained by Gemmizea $11 \mathrm{cv}$. when low N-level of $60 \mathrm{~kg}$ N/fad., was used.

\section{Grain, Straw and Biological Yields/fad.}

Data presented in Table 5 show the influence of sowing dates, nitrogen fertilizer levels and cultivars on grain, straw and biological yields of wheat during both growing seasons and their combined.

Sowing dates affected significantly on each of grain, straw and biological yields of wheat during both growing seasons and their combined (Table 5). The maximum grain yield was recorded when sowing was done on November, $30^{\text {th }}$ compared to early sowing (November $10^{\text {th }}$ ) or late sowing (December $20^{\text {th }}$ ). Also, it is clear from these results that sowing on November $30^{\text {th }}$ increased grain yield by $8.21 \%$ and $23.37 \%$ in the first season and by $11.60 \%$ and $17.26 \%$ in the second season and by $9.82 \%$ and $20.36 \%$ in the combined as compared with early sowing (November, $30^{\text {th }}$ ), respectively. Also, sowing on 
Table 4-a. Number of spikelets /spike as affected by the interaction between sowing dates and cultivars (combined data)

\begin{tabular}{lccc}
\hline Cultivar & \multicolumn{3}{c}{ Sowing date } \\
\cline { 2 - 4 } & November 10 $^{\text {th }}$ & November $\mathbf{3 0}^{\text {th }}$ & December 20 $^{\text {th }}$ \\
\hline \multirow{2}{*}{ Gemmieza 11 } & $\mathrm{B}$ & $\mathrm{A}$ & $\mathrm{B}$ \\
& $18.378 \mathrm{~b}$ & $20.056 \mathrm{~b}$ & $18.611 \mathrm{~b}$ \\
Sids 12 & $\mathrm{B}$ & $\mathrm{A}$ & $\mathrm{B}$ \\
& $21.422 \mathrm{a}$ & $22.722 \mathrm{a}$ & $20.889 \mathrm{a}$ \\
Giza 168 & $\mathrm{B}$ & $\mathrm{A}$ & $\mathrm{B}$ \\
& $17.778 \mathrm{~b}$ & $19.333 \mathrm{~b}$ & $17.078 \mathrm{c}$ \\
Misr 1 & $\mathrm{B}$ & $\mathrm{A}$ & $\mathrm{B}$ \\
& $18.200 \mathrm{~b}$ & $19.511 \mathrm{~b}$ & $18.111 \mathrm{~b}$ \\
\hline
\end{tabular}

Table 4-b. Number of spikelets /spike as affected by the interaction between nitrogen fertilizer levels and cultivars (combined data)

\begin{tabular}{|c|c|c|c|}
\hline \multirow[t]{2}{*}{ Cultivar } & \multicolumn{3}{|c|}{ Nitrogen fertilizer level } \\
\hline & 60 kg/fad. & 90 kg/fad. & $120 \mathrm{~kg} / \mathrm{fad}$. \\
\hline & B & A & A \\
\hline \multirow[t]{2}{*}{ Gemmieza 11} & $18.178 b$ & 19.167b & $19.700 \mathrm{~b}$ \\
\hline & $\mathrm{C}$ & B & A \\
\hline \multirow[t]{2}{*}{ Sids 12} & $20.622 a$ & 21.689a & $22.722 \mathrm{a}$ \\
\hline & $\mathrm{C}$ & B & A \\
\hline \multirow[t]{2}{*}{ Giza 168} & $17.267 \mathrm{c}$ & 18.156c & $18.767 \mathrm{c}$ \\
\hline & B & B & A \\
\hline Misr 1 & 18.189b & $18.278 \mathrm{c}$ & 19.356bc \\
\hline
\end{tabular}

Table 4-c. Number of grains/spike as affected by the interaction between sowing dates and cultivars (combined data)

\begin{tabular}{|c|c|c|c|}
\hline \multirow[t]{2}{*}{ Cultivar } & \multicolumn{3}{|c|}{ Sowing date } \\
\hline & November $10^{\text {th }}$ & November $30^{\text {th }}$ & December $20^{\text {th }}$ \\
\hline & B & A & $\mathrm{C}$ \\
\hline \multirow[t]{2}{*}{ Gemmieza 11} & $52.56 \mathrm{~b}$ & $57.94 \mathrm{~b}$ & $48.55 \mathrm{~b}$ \\
\hline & B & A & $\mathrm{C}$ \\
\hline \multirow[t]{2}{*}{ Sids 12} & $64.11 \mathrm{a}$ & 70.05 a & 61.11 a \\
\hline & $\mathrm{AB}$ & A & B \\
\hline \multirow[t]{2}{*}{ Giza 168} & $48.61 \mathrm{~b}$ & $53.61 \mathrm{c}$ & 44.94 c \\
\hline & $\mathrm{AB}$ & A & B \\
\hline Misr 1 & $51.16 \mathrm{~b}$ & 54.61 c & $46.77 \mathrm{~b}$ \\
\hline
\end{tabular}


Table 4-d. Number of grains/spike as affected by the interaction between nitrogen fertilizer levels and cultivars (combined data)

\begin{tabular}{|c|c|c|c|}
\hline \multirow[t]{2}{*}{ Cultivar } & \multicolumn{3}{|c|}{ Nitrogen fertilizer level } \\
\hline & 60 kg/fad. & 90 kg/fad. & $120 \mathrm{~kg} / \mathrm{fad}$. \\
\hline \multirow{3}{*}{ Gemmieza 11} & $\mathrm{C}$ & B & A \\
\hline & $43.05 \mathrm{c}$ & $53.94 \mathrm{~b}$ & $62.05 \mathrm{~b}$ \\
\hline & B & A & A \\
\hline \multirow[t]{2}{*}{ Sids 12} & 59.66 a & 67.66 a & $67.94 \mathrm{a}$ \\
\hline & B & $\mathrm{B}$ & A \\
\hline \multirow[t]{2}{*}{ Giza 168} & $48.16 \mathrm{~b}$ & 46.55 c & 52.44 c \\
\hline & B & A & A \\
\hline Misr 1 & $47.44 \mathrm{~b}$ & $52.11 \mathrm{~b}$ & $53.00 \mathrm{c}$ \\
\hline
\end{tabular}

Table 4-e. Thousand grain weight (g) of wheat as affected by the interaction between sowing dates and cultivars (combined data)

\begin{tabular}{|c|c|c|c|}
\hline \multirow[t]{2}{*}{ Cultivar } & \multicolumn{3}{|c|}{ Sowing date } \\
\hline & November $10^{\text {th }}$ & November $30^{\text {th }}$ & December $20^{\text {th }}$ \\
\hline & B & A & $\mathrm{AB}$ \\
\hline \multirow[t]{2}{*}{ Gemmieza 11} & 40.67 bc & $44.89 b$ & $42.61 b$ \\
\hline & $A B$ & A & B \\
\hline \multirow[t]{2}{*}{ Sids 12} & $49.11 \mathrm{a}$ & $54.50 \mathrm{a}$ & $46.78 \mathrm{a}$ \\
\hline & A & A & A \\
\hline \multirow[t]{2}{*}{ Giza 168} & $39.28 \mathrm{c}$ & 40.11cd & $38.56 \mathrm{~d}$ \\
\hline & A & A & A \\
\hline Misr 1 & $42.22 \mathrm{~b}$ & 39.56d & 39.61cd \\
\hline
\end{tabular}

Table 4-f. Thousand grain weight (g) of wheat as affected by the interaction between nitrogen fertilizer levels and cultivars (combined data)

\begin{tabular}{|c|c|c|c|}
\hline \multirow[t]{2}{*}{ Cultivar } & \multicolumn{3}{|c|}{ Nitrogen fertilizer level } \\
\hline & 60 kg/fad. & 90 kg/fad. & $120 \mathrm{~kg} / \mathrm{fad}$. \\
\hline & A & A & A \\
\hline \multirow[t]{2}{*}{ Gemmieza 11} & $42.89 \mathrm{~b}$ & $43.72 b$ & $41.56 b$ \\
\hline & B & B & A \\
\hline \multirow[t]{2}{*}{ Sids 12} & 48.33a & 49.06a & $53.00 \mathrm{a}$ \\
\hline & B & A & A \\
\hline \multirow[t]{2}{*}{ Giza 168} & $35.67 b$ & 41.22bc & $41.06 b$ \\
\hline & A & A & A \\
\hline Misr 1 & $39.28 \mathrm{c}$ & $40.44 c$ & $41.67 b$ \\
\hline
\end{tabular}


November $30^{\text {th }}$ produced higher number of spikes/ $\mathrm{m}^{2}$ (Table 3), number of grains/spike and 1000- grain weight values (Table 4) compared with sowing on November $10^{\text {th }}$ and December $20^{\text {th }}$. This indicates that the climatic conditions were not relatively suitable for growth through early or delay sowing dates. So, weather conditions prevailing during wheat growth may be the reason for the detected variations. Another possible and strong attributes could be the high temperature during delay sowing which prolonged the period of grain filling and resulted in reduce development of grain and ultimately decreasing the grain yield (Guilioni et al., 2003). The recorded data indicated that there were highly significant differences between sowing dates in both growing seasons and their combined analysis respecting straw yield of wheat (Table 5). It is clear from obtained results that sowing on November $30^{\text {th }}$ increased straw yield compared with late sowing on December $20^{\text {th }}$ but without significant differences than early sowing (November $10^{\text {th }}$ ) through seasons and the combined. These increments in straw yield might be due to the increase in number of tillers $/ \mathrm{m}^{2}$ and plant height (Table 3). Also, it might be attributed to the chance given to plants of appropriateness sowing to receive higher heat summation, intercepted light and energy with prolonging the growth period which in turn on metabolic processes translocation of synthesized metabolites and its accumulation in plant. In this connection, Geith et al. (2013) found that delay in sowing from November $25^{\text {th }}$ to December $25^{\text {th }}$ produced low straw yield. The recorded data obvious revealed that there were significant differences between sowing dates in both growing seasons and their combined analysis in biological yield of wheat (Table 5). It is clear from these results that sowing on November, $30^{\text {th }}$ increased biological yield by $15.41 \%$ and $35.30 \%$ in the first season and by $18.05 \%$ and $31.19 \%$ in the second season and by $16.38 \%$ and $33.17 \%$ in the combined data as compared with sowing on November $10^{\text {th }}$ and December $20^{\text {th }}$, respectively. These increments in biological yield achieved by moderate sowing (November $30^{\text {th }}$ ) might be due to the increase in grain yield /fad., and straw yield /fad., (Table 5) compared with early sowing (November $10^{\text {th }}$ ) and late sowing (December $20^{\text {th }}$ ). Combined data showed that a lot of decrease in yield due to delay in sowing time. The first reason may be more suitable climatic condition for maximum vegetative and reproductive components which increased biomass yield. Secondly it may be due to reproductive plants unit area. In later sowing date's biomass and grain yields decreased due to undesired environmental conditions and lack of suitable transforming preserved matters to seeds as a result of increasing temperature at the end of growth season (Emami et al., 2011). Many investigators concluded that appropriate sowing date is important to have the crop in the field. Similar trends were reported by El-Gizawy (2009), Amin (2010), Swelam et al. (2010), ElSarag and Ismaeil (2013) and Fayed et al. (2015).

Concerning the influence of nitrogen fertilizer level on grain, straw and biological yields/ fad., the results in Table 5 indicated significant differences in both seasons and their combined, where increasing nitrogen fertilizer level from 60 or 90 up to $120 \mathrm{~kg} \mathrm{~N} /$ fad., significantly increased grain, straw and biological yields/fad., while the grain yield responded up to $90 \mathrm{~kg} \mathrm{~N} / \mathrm{fad}$., only, in the first season. Such results could be attributed to the promotion effect of nitrogen on vegetative growth which in turn favored metabolic processes and increased all yield attributes as mentioned before. The positive response of grain and straw yields of wheat to nitrogen fertilization was noticed by several investigators in the literature as Abdul Galil et al. (2003), Ali et al. (2004), El-Gizawy (2010), Swelam et al. (2010), Iqbal et al. (2012), Abd El-Razek et al. (2013), Geith et al. (2013) and Khalid et al. (2014).

Regarding wheat cultivars effect, the results revealed highly significant differences between grain, straw and biological yields/fad., in both growing seasons and their combined analysis. As far as, varietal differences concerning grain and biological yields/fad., the results in Table 5 clearly show the superiority of Misr 1 followed by Gemmizea 11 but without significant differences between them and then by Sids 12 which was at par with Giza 168 (combined analysis). These results are rather expected as Misr 1 recorded the highest number of spikes $/ \mathrm{m}^{2}$ (Table 3) followed by Gemmizea 11 which had the heavier 1000-grain after Sids 12 (Table 4). 
Table 5. Grain yield (ardab/faddan), straw yield (ton/fad.)and biological yield (ton/fad.) of wheat as affected by sowing dates, nitrogen fertilizer levels, cultivars and their interactions during two successive winter seasons $(2013 / 2014$ and $2014 / 2015)$ as well as their combined

\begin{tabular}{|c|c|c|c|c|c|c|c|c|c|}
\hline \multirow[t]{2}{*}{$\begin{array}{l}\text { Main effects and } \\
\text { interactions }\end{array}$} & \multicolumn{3}{|c|}{$\begin{array}{l}\text { Grain yield } \\
\text { (ardab/fad.) }\end{array}$} & \multicolumn{3}{|c|}{$\begin{array}{c}\text { Straw yield } \\
\text { (ton/fad.) }\end{array}$} & \multicolumn{3}{|c|}{$\begin{array}{c}\text { Biological yield } \\
\text { (ton/fad.) }\end{array}$} \\
\hline & $\begin{array}{c}1^{\text {st }} \\
\text { season } \\
\end{array}$ & $\begin{array}{c}2^{\text {nd }} \\
\text { season } \\
\end{array}$ & Com. & $\begin{array}{c}1^{\text {st }} \\
\text { season } \\
\end{array}$ & $\begin{array}{c}2^{\text {nd }} \\
\text { season } \\
\end{array}$ & Com. & $\begin{array}{c}1^{\text {st }} \\
\text { season } \\
\end{array}$ & $\begin{array}{c}2^{\text {nd }} \\
\text { season } \\
\end{array}$ & Com. \\
\hline \multicolumn{10}{|l|}{ Sowing date (S) } \\
\hline November $10^{\text {th }}$ & $21.07 b$ & $18.44 \mathrm{~b}$ & $19.75 b$ & $3.78 \mathrm{ab}$ & 4.32ab & $4.05 \mathrm{ab}$ & $6.94 b$ & $7.09 \mathrm{~b}$ & $7.01 \mathrm{ab}$ \\
\hline November $30^{\text {th }}$ & $22.80 \mathrm{a}$ & $20.58 a$ & $21.69 a$ & $4.59 \mathrm{a}$ & $5.29 \mathrm{a}$ & $4.94 \mathrm{a}$ & 8.01a & $8.37 \mathrm{a}$ & 8.19a \\
\hline December $20^{\text {th }}$ & $18.48 \mathrm{c}$ & $17.55 \mathrm{c}$ & $18.02 \mathrm{c}$ & $3.15 b$ & $3.75 b$ & $3.45 b$ & $5.92 \mathrm{c}$ & $6.38 b$ & $6.15 b$ \\
\hline F. test & $* *$ & $* *$ & $* *$ & $* *$ & $* *$ & $* *$ & $*$ & $*$ & $*$ \\
\hline \multicolumn{10}{|c|}{ Nitrogen fertilizer level (N) } \\
\hline 60 kg/fad. & $18.92 b$ & $17.92 b$ & $18.42 \mathrm{~b}$ & $2.89 \mathrm{~b}$ & $3.97 b$ & $3.43 b$ & $5.73 c$ & $6.66 \mathrm{c}$ & $6.20 c$ \\
\hline 90 kg/fad. & $21.22 \mathrm{a}$ & $18.58 \mathrm{~b}$ & $19.90 \mathrm{~b}$ & $3.64 b$ & $4.48 b$ & $4.06 \mathrm{~b}$ & $6.82 \mathrm{~b}$ & $7.27 b c$ & $7.05 b$ \\
\hline 120 kg/fad. & $22.21 \mathrm{a}$ & $20.08 \mathrm{a}$ & $21.14 \mathrm{a}$ & $4.98 \mathrm{a}$ & $4.91 \mathrm{a}$ & $4.95 a$ & $8.31 \mathrm{a}$ & $7.92 \mathrm{a}$ & $8.12 \mathrm{a}$ \\
\hline F. test & $* *$ & $*$ & $* *$ & $* *$ & $* *$ & $* *$ & $* *$ & $* *$ & $* *$ \\
\hline \multicolumn{10}{|l|}{ Cultivars (C) } \\
\hline Gemmeiza 11 & $20.92 a$ & $18.85 b$ & 19.88ab & $3.90 \mathrm{~b}$ & 4.69ab & $4.29 b$ & $7.04 \mathrm{~b}$ & 7.47ab & $7.25 \mathrm{ab}$ \\
\hline Sids 12 & 20.58ab & $18.52 b$ & $19.55 b$ & $3.59 b c$ & $4.12 \mathrm{bc}$ & $3.85 b c$ & $6.67 \mathrm{bc}$ & $6.89 \mathrm{bc}$ & $6.78 \mathrm{bc}$ \\
\hline Giza 168 & $19.76 b$ & $17.96 \mathrm{~b}$ & $18.86 b$ & $3.23 c$ & $3.74 \mathrm{c}$ & $3.48 \mathrm{c}$ & $6.19 c$ & $6.43 c$ & $6.31 \mathrm{c}$ \\
\hline Misr 1 & $22.18 \mathrm{a}$ & $20.11 \mathrm{a}$ & 21.14a & 4.63a & $5.27 \mathrm{a}$ & $4.95 \mathrm{a}$ & $7.95 \mathrm{a}$ & $8.28 \mathrm{a}$ & $8.11 \mathrm{a}$ \\
\hline F. test & $* *$ & $* *$ & $* *$ & $* *$ & $* *$ & $* *$ & $* *$ & $* *$ & $* *$ \\
\hline \multicolumn{10}{|l|}{ Interactions } \\
\hline $\mathrm{S} \times \mathrm{N}$ & NS & NS & NS & NS & NS & NS & NS & NS & $*$ \\
\hline $\mathrm{S} \times \mathrm{C}$ & $*$ & NS & $* *$ & NS & NS & $*$ & NS & NS & NS \\
\hline $\mathrm{N} \times \mathrm{C}$ & NS & $*$ & $*$ & NS & $*$ & $*$ & NS & $*$ & $* *$ \\
\hline
\end{tabular}

*, ** and NS indicate significant at 0.05 and 0.01 levels and insignificant of differences, in respective order.

Concerning biological yield, Misr 1cv was the highest one (8.11 ton/fad.) followed by either Gemmizea $11 \mathrm{cv}$ (7.25 ton/fad.) or Sids 12 (6.78 ton/fad.), while Giza $168 \mathrm{cv}$ scored lowest one (6.31 ton/fad.) according to combined analysis results. These results may be attributing to the differences among cultivars under study in growth habit and response of each one to the environmental conditions during the growing seasons which controlled by genetical factors. Such responses reflected on growth characteristics and consequently yield attributes and ultimately grain yield .Several investigators showed such great differences among wheat cultivars regarding grain and straw yields included Ashmawy and Abo-Warda (2002), Amin (2010), Geith et al. (2013) and Noureldin et al. (2013).

Likely, the significant interaction between nitrogen fertilizer levels and cultivars in the combined data (Table 5-a) indicated that, the highest grain yield (22.13 ardab/fad.) was achieved by Misr $1 \mathrm{cv}$. when received $120 \mathrm{~kg}$ $\mathrm{N} / \mathrm{fad}$. On the other hand the lowest grain yield (17.41 ardab/fad.,) was obtained by Giza 168 cv. when received $60 \mathrm{~kg} \mathrm{~N} / \mathrm{fad}$. With respect to the significant interaction between sowing dates and cultivars at (Table 5-b), the significant interaction between sowing dates and wheat cultivars in the combined analysis showed that 
Table 5-a. Grain yield (ardab /fad) as affected by the interaction between nitrogen fertilizer levels and cultivars (combined data)

\begin{tabular}{lccc}
\hline Cultivar & \multicolumn{3}{c}{ Nitrogen fertilize level } \\
\cline { 2 - 4 } & $\mathbf{6 0} \mathbf{~ k g / f a d}$ & $\mathbf{9 0} \mathbf{~ k g} / \mathbf{f a d}$. & $\mathbf{1 2 0} \mathbf{~ k g} / \mathbf{f a d} \mathbf{~}$ \\
\hline \multirow{2}{*}{ Gemmieza 11 } & $\mathrm{B}$ & $\mathrm{AB}$ & $\mathrm{A}$ \\
& $18.27 \mathrm{bc}$ & $19.81 \mathrm{ab}$ & $21.57 \mathrm{a}$ \\
Sids 12 & $\mathrm{B}$ & $\mathrm{B}$ & $\mathrm{A}$ \\
& $18.28 \mathrm{bc}$ & $18.99 \mathrm{~b}$ & $20.94 \mathrm{ab}$ \\
Giza 168 & $\mathrm{B}$ & $\mathrm{A}$ & $\mathrm{A}$ \\
& $17.41 \mathrm{c}$ & $19.23 \mathrm{~b}$ & $19.94 \mathrm{~b}$ \\
Misr 1 & $\mathrm{B}$ & $\mathrm{AB}$ & $\mathrm{A}$ \\
& $19.71 \mathrm{a}$ & $21.58 \mathrm{a}$ & $22.13 \mathrm{a}$ \\
\hline
\end{tabular}

Table 5-b. Grain yield of wheat (ardab/fad.) as affected by the interaction between sowing dates and cultivars (combined data)

\begin{tabular}{lccc}
\hline Cultivar & \multicolumn{3}{c}{ Sowing date } \\
\cline { 2 - 4 } & ${\text { November } \mathbf{~ 1 0}^{\text {th }}}^{\text {Govember } \mathbf{3 0}^{\text {th }}}$ & Necember20 $^{\text {th }}$ \\
\hline Gemmieza 11 & $\mathrm{B}$ & $\mathrm{A}$ & $\mathrm{B}$ \\
& $19.34 \mathrm{~b}$ & $21.53 \mathrm{~b}$ & $18.77 \mathrm{~b}$ \\
Sids 12 & $\mathrm{B}$ & $\mathrm{A}$ & $\mathrm{C}$ \\
& $19.54 \mathrm{bc}$ & $21.48 \mathrm{~b}$ & $17.18 \mathrm{~b}$ \\
Giza 168 & $\mathrm{B}$ & $\mathrm{A}$ & $\mathrm{B}$ \\
& $18.93 \mathrm{c}$ & $20.49 \mathrm{c}$ & $17.15 \mathrm{~b}$ \\
Misr 1 & $\mathrm{B}$ & $\mathrm{A}$ & $\mathrm{C}$ \\
\hline
\end{tabular}

the highest grain yield (23.26 ardab/fad.) was obtained by Misr $1 \mathrm{cv}$. with sowing on November, $30^{\text {th }}$, while the lowest grain yield (18.93 ardab/fad.) was recorded by Giza $168 \mathrm{cv}$. with sowing on November, $10^{\text {th }}$. The significant interaction between cultivars and sowing dates shows the sensitivity of different cultivars to photoperiod and temperature differently for grain yield of wheat. Data obtained in (Table 5c) revealed the significant effect of interaction between sowing dates and wheat cultivars on straw yield (combined data). Misr $1 \mathrm{cv}$ recorded the maximum straw yield (5.87 t/fad.) when sowing was done on November $30^{\text {th }}$, while Giza $168 \mathrm{cv}$ recorded the minimum straw yield (2.84 $\mathrm{t} / \mathrm{fad}$.) when sowing was done on December $20^{\text {th }}$. The significant interaction between cultivars and sowing dates shows the sensitivity of different cultivars to photoperiod and temperature differently for straw yield of wheat. Furthermore, the significant interaction between nitrogen fertilizer levels and wheat cultivars in the combined analysis (Table 5-d) indicated that the highest straw yield of 5.75 ton/fad., was achieved by Misr $1 \mathrm{cv}$., when high nitrogen fertilizer levels of $120 \mathrm{~kg} \mathrm{~N} / \mathrm{fad}$., was applied (combined data). On the other hand, the lowest straw yield (3.21 ton/fad.) was obtained by Giza $168 \mathrm{cv}$., when low nitrogen fertilizer level of 60 kg N/fad., was used.

Regarding the significant interaction between sowing dates and nitrogen fertilizer levels on biological yield (Table 5-e), the results showed that maximum biological yield (9.231 ton/fad.) was obtained with wheat sowing on November $30^{\text {th }}$ and received $120 \mathrm{~kg} \mathrm{~N} /$ fad., while minimum one (5.579 t/fad.) was recorded with wheat sowing on December, $20^{\text {th }}$ and received $60 \mathrm{~kg}$ $\mathrm{N} /$ fad. Furthermore, the significant interaction between nitrogen fertilizer levels and wheat cultivars in the combined analysis (Table 5-f) 
Table 5-c. Straw yield (ton/fad.) as affected by the interaction between sowing dates and cultivars (combined data)

\begin{tabular}{lccc}
\hline Cultivar & \multicolumn{3}{c}{ Sowing date } \\
\cline { 2 - 4 } & ${\text { November } \mathbf{~ 1 0}^{\text {th }}}^{\text {Gemmieza 11 }}$ & November $\mathbf{3 0}^{\text {th }}$ & December 20 $^{\text {th }}$ \\
\hline \multirow{2}{*}{ Sids 12 } & $4.28 \mathrm{~b}$ & $\mathrm{~A}$ & $\mathrm{~B}$ \\
& $\mathrm{~B}$ & $5.02 \mathrm{ab}$ & $3.57 \mathrm{ab}$ \\
Giza 168 & $3.40 \mathrm{c}$ & $\mathrm{A}$ & $\mathrm{B}$ \\
& $\mathrm{AB}$ & $4.83 \mathrm{~b}$ & $3.32 \mathrm{ab}$ \\
Misr 1 & $3.57 \mathrm{c}$ & $\mathrm{A}$ & $\mathrm{B}$ \\
& $\mathrm{AB}$ & $4.02 \mathrm{~b}$ & $2.84 \mathrm{~b}$ \\
& $4.93 \mathrm{a}$ & $\mathrm{A}$ & $\mathrm{B}$ \\
& & $5.87 \mathrm{a}$ & $4.04 \mathrm{a}$ \\
\hline
\end{tabular}

Table 5-d. Straw yield (ton/fad.) as affected by the interaction between nitrogen fertilizer levels and cultivars (combined data)

\begin{tabular}{lccc}
\hline Cultivar & \multicolumn{3}{c}{ Nitrogen fertilizer level } \\
\cline { 2 - 4 } & $\mathbf{6 0} \mathbf{~ k g / f a d}$. & $\mathbf{9 0} \mathbf{~ k g} / \mathbf{f a d} \mathbf{~}$ & $\mathbf{1 2 0} \mathbf{~ k g} / \mathbf{f a d} \mathbf{~}$ \\
\hline \multirow{2}{*}{ Gemmieza 11 } & $\mathrm{B}$ & $\mathrm{B}$ & $\mathrm{A}$ \\
& $3.39 \mathrm{ab}$ & $4.23 \mathrm{~b}$ & $5.24 \mathrm{a}$ \\
Sids $\mathbf{1 2}$ & $\mathrm{B}$ & $\mathrm{B}$ & $\mathrm{A}$ \\
& $3.31 \mathrm{ab}$ & $3.44 \mathrm{c}$ & $4.81 \mathrm{ab}$ \\
Giza 168 & $\mathrm{B}$ & $\mathrm{B}$ & $\mathrm{A}$ \\
& $3.21 \mathrm{~b}$ & $3.25 \mathrm{c}$ & $3.98 \mathrm{~b}$ \\
Misr 1 & $\mathrm{B}$ & $\mathrm{A}$ & $\mathrm{A}$ \\
\hline
\end{tabular}

Table 5-e. Biological yield (ton/fad.) as affected by the interaction between sowing dates and nitrogen fertilizer levels (combined data)

\begin{tabular}{|c|c|c|c|}
\hline \multirow{2}{*}{$\begin{array}{c}\text { Nitrogen fertilizer } \\
\text { level }\end{array}$} & \multicolumn{3}{|c|}{ Sowing date } \\
\hline & November $10^{\text {th }}$ & November $30^{\text {th }}$ & December $20^{\text {th }}$ \\
\hline & B & $\bar{A}$ & $\mathrm{C}$ \\
\hline \multirow[t]{2}{*}{$60 \mathrm{~kg}$ N/fad. } & 5.963 c & 7.037c & $5.579 b$ \\
\hline & B & A & $\mathrm{AB}$ \\
\hline \multirow[t]{2}{*}{$90 \mathrm{~kg}$ N/fad. } & $7.050 \mathrm{~b}$ & $8.309 b$ & $7.786 a$ \\
\hline & $\mathrm{AB}$ & A & B \\
\hline $120 \mathrm{~kg}$ N/fad. & $8.032 \mathrm{a}$ & $9.231 \mathrm{a}$ & $7.088 \mathrm{a}$ \\
\hline
\end{tabular}


Table 5-f. Biological yield (ton/fad.) as affected by the interaction between nitrogen fertilizer levels and cultivars (combined data)

\begin{tabular}{cccc}
\hline Cultivar & \multicolumn{3}{c}{ Nitrogen fertilizer level } \\
\cline { 2 - 4 } & $\mathbf{6 0} \mathbf{~ k g / f a d}$ & $\mathbf{9 0} \mathbf{~ k g} / \mathbf{f a d}$. & $\mathbf{1 2 0} \mathbf{~ k g} / \mathbf{f a d}$. \\
\hline \multirow{2}{*}{ Gemmieza 11 } & $\mathrm{B}$ & $\mathrm{B}$ & $\mathrm{A}$ \\
& $6.028 \mathrm{a}$ & $7.174 \mathrm{~b}$ & $8.555 \mathrm{ab}$ \\
Sids 12 & $\mathrm{B}$ & $\mathrm{B}$ & $\mathrm{A}$ \\
& $6.072 \mathrm{a}$ & $6.327 \mathrm{c}$ & $7.969 \mathrm{~b}$ \\
Giza 168 & $\mathrm{B}$ & $\mathrm{A}$ & $\mathrm{A}$ \\
& $6.010 \mathrm{a}$ & $6.129 \mathrm{c}$ & $6.812 \mathrm{c}$ \\
Misr 1 & $\mathrm{B}$ & $\mathrm{A}$ & $\mathrm{A}$ \\
& $6.662 \mathrm{a}$ & $8.562 \mathrm{a}$ & $9.132 \mathrm{a}$ \\
\hline
\end{tabular}

indicated that the highest biological yield of 9.132 ton/fad., was obtained by Misr 1 cv., when nitrogen fertilizer level of $120 \mathrm{~kg} \mathrm{~N} / \mathrm{fad}$., was applied as well as when $90 \mathrm{~kg} \mathrm{~N} / \mathrm{fad}$., was applied (8.562 ton/fad.) followed by Gemmizea $11 \mathrm{cv}$., when nitrogen fertilizer level of $120 \mathrm{~kg}$ $\mathrm{N} /$ fad., was applied. On the other hand, the lowest biological yield was obtained under application of $60 \mathrm{~kg} \mathrm{~N} /$ fad., for all cultivars.

\section{REFERENCES}

Abd El-Kreem, T.H.A. and E.G.G. Ahmed (2013). Evaluation of four new bread wheat (Triticum aestivum L.) cultivars in sandy soils under different irrigation regimes. Alex. J. Agric. Res., 58 (3): 241-250.

Abd El-Lattief, E.A. (2014). Determining the optimization seeding rate for improved productivity of wheat under Southern Egypt conditions. Int. J. Agron. and Agric. Res. (IJAAR) ISSN: 2223-7054 (Print) 2225-3610 (Online), 4 (1): 47-57.

Abd El-Razek, U.A. and A.A. El-Sheshtawy (2013). Response of some wheat varieties to bio and mineral nitrogen fertilizers. Asian J. Crop Sci., 5: 200-208.

Abdul Galil, A.A., H.A. Basha, S.A.E. Mowafy and S.M.M. Ahmed (2003). Effect of phosphorus addition on the response of four wheat cultivars to $\mathrm{N}$ fertilization levels under sandy soil conditions. Minufiya J. Agric. Res., 28 (1):1-22.

Aftab W., A. Hussain A. Ahmad, A.R. Goheer, M. Ibrahim and M. Mussaddique (2004). Effect of sowing dates and plant population on biomass, grain yield and yield components of wheat. Int. J. Agric. Bio., 1003 - 1005.

Ahmed, S.M.M. (2009). Response of wheat to fertilization under sandy soil conditions. Ph. D. Thesis, Fac. Agric., Zagazig Univ., Egypt.

Akhtar, M., M.S. Cheema, M. Jamil and L. Ali (2006). Effect of time of sowing on some Important characters of wheat (Triticum aestivum L.). Genotypes J. Agric. Res., 44 (4): 255-259.

Ali, A.G.A., O.E. Zeiton, A.H. Bassiauny and A.R.Y.A. El-Banna (2004). Productivity of wheat cultivars grown at El-Khattara and ElArish under different levels of planting densities and $\mathrm{N}$ Fertilization. Zagazig $\mathrm{J}$. Agric. Res., 31 (4 A):1225-1256.

Amin, El.H.M. (2010). Agronomic practices affecting growth and productivity of certain wheat cultivars in the new cultivated soils. Ph. D. Thesis, Fac. Agric, Zagazig Univ., Egypt. 
Ashmawy, F. and A.M.A. Abo-Warda (2002). Response of some wheat cultivars to different seeding rates and nitrogen fertilization levels in sandy soil. Egypt. J. Appl. Sci., 17 (10):136-157.

Duncan, D.B. (1955). Multiple Range and Multiple F-test. Biometric, 11: 1-24.

El-Gizawy, N. (2009). Effect of planting date and fertilizer application on yield of wheat under no till system. World J. of Agric. Sci. 5: 777-783.

El-Gizawy N, (2010). Effect of nitrogen, biogas sluge manure and biofertilizer on grain nitrogen up take and yield of wheat. (Triticum aestivum L.). The Int. Conf. of Agron. 20-22 Sept., El-Arish, 1-13.

El-Sarag, E.I. and R.I.M. Ismaeil (2013). Evaluation of some bread wheat cultivars productivity as affected by sowing dates and water stress in Semi-arid region. Asian J. Crop Sci., 5: 167-178.

Emami, S., V. Meda and R.T. Tyler (2011). Effect of micronisation and electromagnetic radiation on physical and mechanical properties of Canadian barley. Int. J. Food Sci. and Technol., 46: 421-428.

Fayed, T. B., I. Eman, M.K. Hassanein and A. Magdy (2015). Evaluation and prediction of some wheat cultivars productivity in relation to different sowing dates under North Sinai region conditions. Ann. Agric. Sci., 60 (1): $11-20$.

Geith, E.M.S., O.Z. El-Badry and S.A. Wahid (2013). Response of growth and straw yield of some wheat genotypes to sowing dates and nitrogen levels. Zagazig J. Agric. Res., 40 : (5): 809-815.

Guilioni, L., J. Wery and J. Lecoeur (2013). High temperature and water deficit may reduce seed number in field pea purely by decreasing plant growth rate, Funct. Plant Biol., 30: 1151-1164.

Hafez, E.M., S.H. Aboukhadrah, S. Gh, R. Sorour and A.R. Yousef (2012). Comparison of agronomical and physiological nitrogen use efficiency in three cultivars of wheat as affected by different levels of $\mathrm{N}$-sources.
Proceedings of the $13^{\text {th }}$ Int. Agron. Conf., Fac. Agric. Benha Univ., Egypt, 30.

Hardan, A.A. (2008). Effect of sowing date on wheat yield productivity under nejd desert region, J. Prod. Dev., 13 (2): 443-455.

Hassan, A.A. and A.B. Gaballah (2000). Response of some wheat cultivars to different levels and sources of $\mathrm{N}$ fertilization under new reclaimed sandy soils. Zagazig J. Agric. Res., 27 (1): 13-29.

Iqbal, J., H. Khizer and S. Hussain (2012). Effect of sowing dates and nitrogen levels on yield and yield components of wheat (Tiriticum aestivum L.). Pak. J. Nutri., 11 (7): 531-536.

Khalid, M., M.F.S. Ali, M.W. Pervez, M. Rehman, S. Hussain and Kh. Rehman (2014). Optimization of nitrogen fertilizer level for newly evolved wheat (Triticum aestivumL.) cultivars. App. Sci. Report., 3 (2): 83-87.

Mehasen, S.A.S. and N.A. Mohamed (2005). Multivariate and response curve analyses for yield and its attributes in some wheat cultivars under nitrogen fertilization levels. Egypt. J. Appl. Sci., 20 (2): 93-109.

Ministry of Agriculture and Land Reclamation (2012). Statistics of agricultural production. Economic Affairs Sector, Ministry of Agriculture and Land Reclamation, Egypt.

Noureldin, N.A., H.S. Saudy, F. Ashmawy and H.M. Saed (2013). Grain yield response index of bread wheat cultivars as influenced by nitrogen levels. Ann. Agric. Sci., 58:147-152.

Ragab (2011). Effect of different levels of NPK on wheat crop in North Delta. In: Böden Lebensgrundlage und Verantwortung, $7-12$. September 2013, Rostock.

Randhawa, A.S., R.S. Jolly and S.S. Dhillon (1977). Response of wheat and barley to nitrogen and different dates of sowing. Crop Improv., 41 (1): 49-64.

Sawires, E.S. (2000). Yield and yield attributes of wheat in relation to nitrogen fertilization and withholding of irrigation to different stages of growth. Ann. Agric. Sci., Ain Shams Univ., Cairo, 45 (2): 439-452. 
Shafiq, H.M. (2004). Modeling growth, radiation use efficiency and yield of wheat at different sowing dates and nitrogen levels under arid conditions of Bhawalpur. M.Sc. (Hons.) Thesis, Univ. Agric., Faisalabad-Pakistan,

Snedecor, G.W. and W.G. Cochran (1981). Statistical Methods. $7^{\text {th }}$ Ed., Iowa State Univ., Press, Ames, Iowa , USA.

Steel, R.G.D., J.H. Torrie and D.A. Dickey (1997). Principles and Procedures of Statistics. A biometrical approach. $3^{\text {rd }}$ Ed., McGraw Hill Book Co., New York, USA.
Swelam, A.A., E.S. Mohamed and H.S. Sayed (2010). Effect of sowing date and nitrogen, fertilization levels on productivity and technological qualities of some bread wheat genotypes. Egypt. J. Appl. Sci., 25 (11): 472485.

Youssef, S.M., S.E.D. Faizy, S.A. Mashali, H. R. El-Ramady and Sh. Ragab (2013). Effect of different levels of NPK on wheat crop in North Delta. J.der Deutschen Bodenkundlichen Gesellschaft vom 07. Bis., 12.

\section{استجابة بعض أصناف القمح لاختلاف ميعاد الزراعة ومستوى السماد النيتروجينى تحت ظروف الإمله الأراضى الرملية}

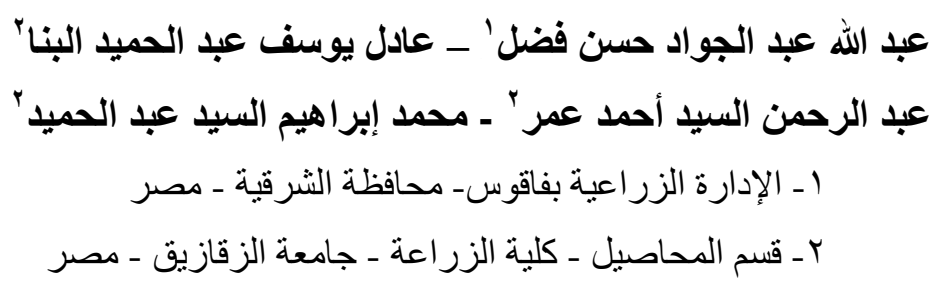

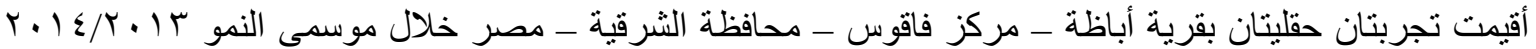

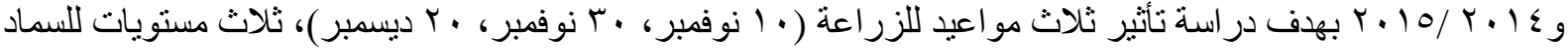

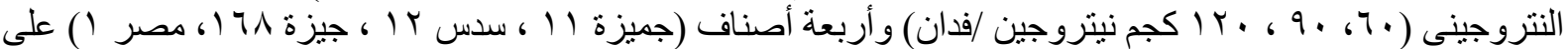

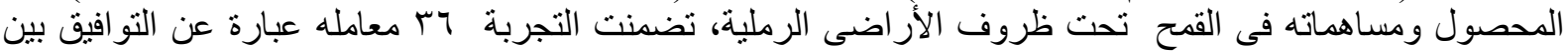

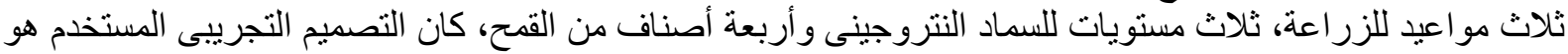

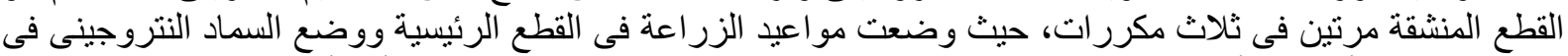

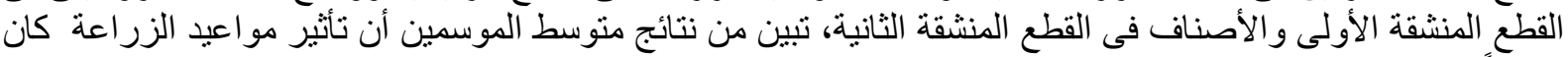

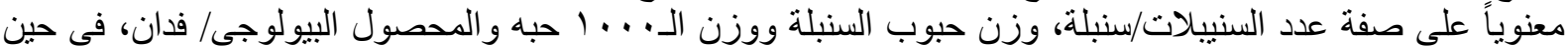

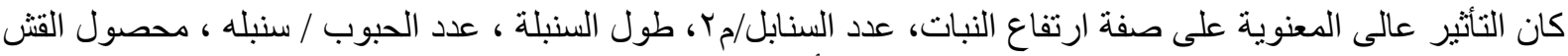

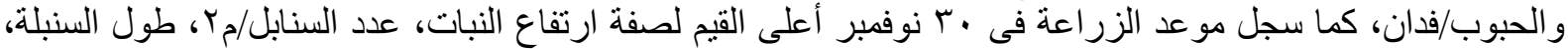

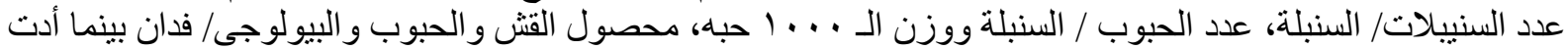

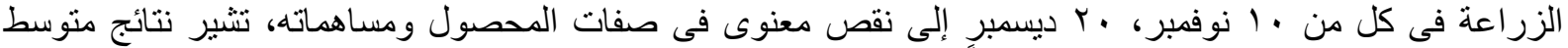

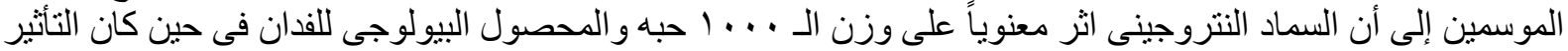

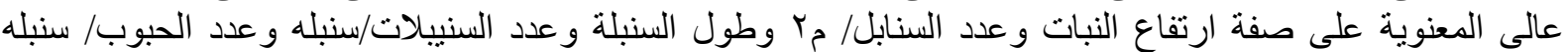

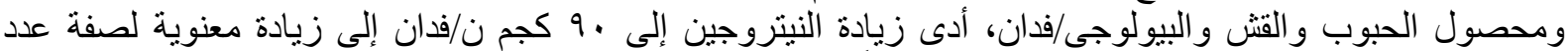

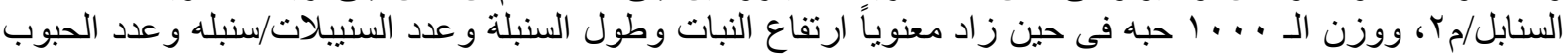

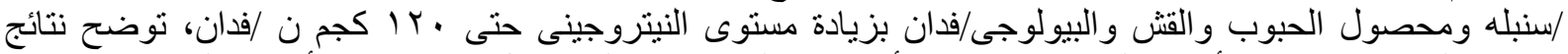

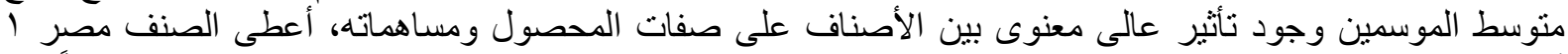

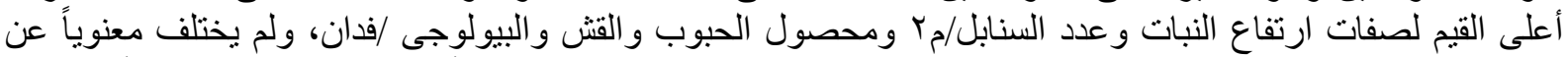

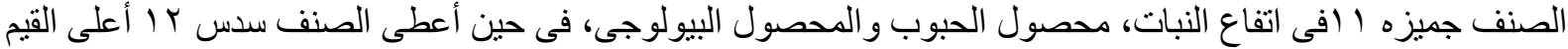

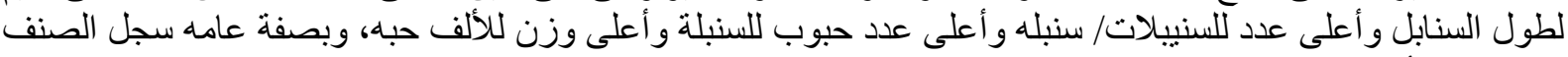

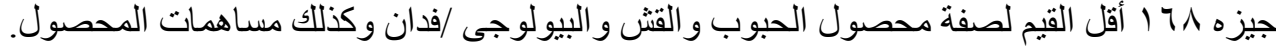

أستاذ ورئيس قسم المحاصيل ــكلية الزر اعة بالإسماعيلية- جامعة قناة السويس. أستاذ المحاصيل المتفرغ - كلية الزر اعة - جامعة الزقازيق. 
